\title{
تقويم تنفيذ برنامج التربة العملية في مدارس التعلم الأساسي من وجهة نظر الطلبة المطبقين
}

\author{
م.م هاجر حسين حسن، قسم التاريخ، كلية التربية الأساسية، جامعة دهوك، أقليم كوردستان العراق
}

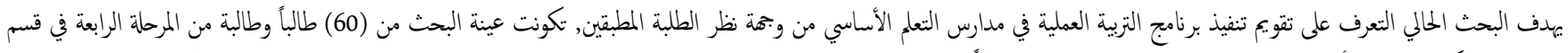

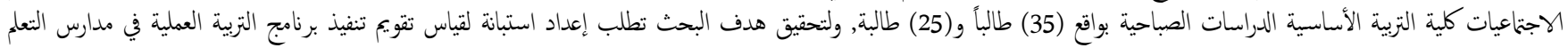

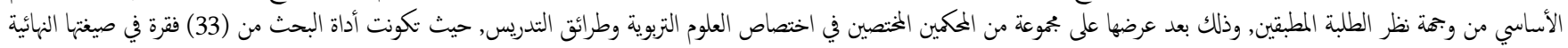

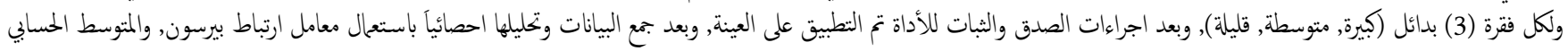

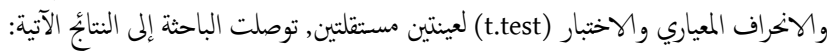

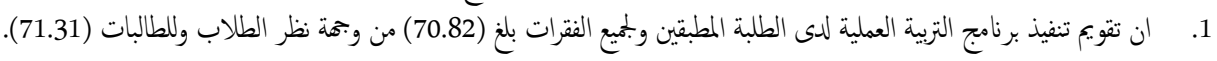

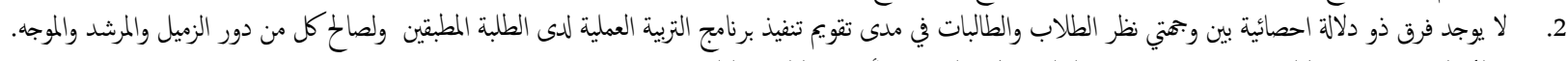

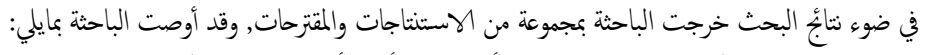

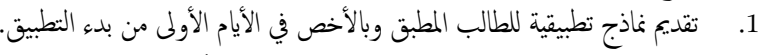
2. توفير المكان المناسب للطلبة/ المطبقين إذ برى أنه من الأنسب أن ينصهر الطالب/ المطبق مع كادر المدرسة الأساسي, ليتسنى له التكيف مع بيئة المدرسة ويكتسب المبرة من لنهه. كلمات الافتتاحية: (تقويم ، برنامج التزبية العملية، مدارس التعلم الاساسي، طلبة المطبقين).

1. 1 - 1 n مشكلة البحث

يحصل الطلبة المطبقون على تدريبات مناسبة وكافية على تلك المارسات

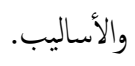
وتأسيسا على ما تقدم تحدد مشكلة البحث بالأسئة الآتية: ما تقو.م تنفيذ برنامج التربية العملية في مدارس التعلم الأساسي من وبحة

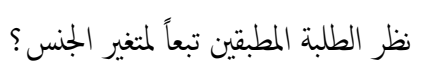

هل هناك فرق في تقويم تنفيذ برنامج التربية العملية في مدارس التعلم الأساسي من وبحة نظر الطلبة المطبقين تبعاً لمتغير الجنس (ذكور / إناث)؟

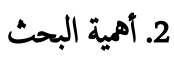

تتصدر قضية إعداد وتأهيل المعلمين مشاريع تطوير التعليم العالي في العديد من دول العالم؛ إذ إن المعلم هو المحور الرئيس في العملية التعلمية التربوية والذي يتوقف على تحسينها وجعلها إيهابية ومفيدة تتوافق مع طبيعة الحياة والتغيرات

$$
\text { الحاصلة في الجمتمعات .(علي, 2012: 49) }
$$

إذ إن إعداد المعلم يخظى باهتمام كير في الآونة الأخيرة سواء آكان ذلك عالمياً أم محلياً، من حيث إعداده وتدريبه، وتقويمه، ويعد امتلاك المعلم للكفايات المهنية الأساسية من المقومات الضرورية للمعلم الكفه من أجل تهيئة الظروف اللازمة لإيماد البيئة الصالحة للتعليم دون هدر في الوقت والجهد. فالمعلم يمثل الركيزة الأساسية في عملية التعليم، إذن لا بد من أن يخظى إعداده بالاهتمام والدراسة؛
اهتمت الدول الخختلفة بإعداد المعلمين عامة, وأنشأت المعاهد والكليات لهذا الغرض, وأصبح الحصول على درجة علمية من تلك الكليات شرطاً للالتحاق بههنة التعليم

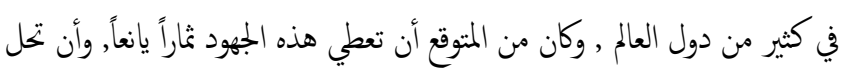
المشكلة بإعداد المعلمين, بيد أن الواقع لا يبدو مشجعاً, فهناك شكوى من تدني مخرجات التعليم في كافة مراحل التعليم, ومن المهم الإيضاح ان ذلك لا يعود بالكامل لعوامل تتعلق بالمعلمين فقط, ولكن هناك بعض العوامل تتعلق بالمعلمين وببرامج تربيهم منها: عدم قدرة مؤسسات التي تعني بتربية المعلمين على مواكبة التطورات التي حدثت في العصر المعاصر, حيث في هذا العصر تتسارع فيه المعرفة وتتجه الأظظار إلى موابجة التحديات. نجد أن هنالك شريحة كيرة وواسعة من المدرسين والمدرسات ليسوا بالمستوى المطلوب من التأهيل العلمي والتربوي والمهني مما جعل شخصيته مهزوزة وضعيفة داخل مدرسته. وان الكثير من المعلمين الجدد يعانون أوضاعاً صعباً في تكيفهم في بداية حياته العملية, وقد يكون ذلك ناجاً عن أمور تتعلق بعملية اعدادهم في مراحل دراستهم الجامعية. ويتفق الكثير من الباحثين والمارسين ان برامج أعداد المعلمين قبل الخدمة لا تعد الخزيين بشكل جيد ليفي بمتطلبات التعليم الحقيقية, وان العديد من الممارسات السلوكية التعليمة لها أثر في تحصيل الطلبة إلا أنه من غير المعروف إلى أي مدى 


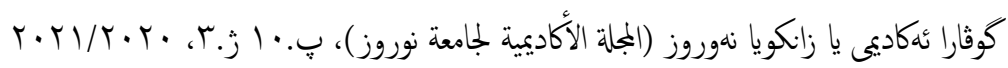

في الثدريب موزعة على السنتين الثالثة والرابعة ، فني السنة الثالثة في المدارس

الإعدادية والسنة الرابعة في المدارس الثانوية (الشيباني وجامل,1997: 302)

وتعطى أنشطة التربية العملية مكانة كمة في مناجه: إعداد المعلمين في دول العالم كفة نظراً للأثر المهم الذي تؤديه في تأهبلهم بوصفها البوتقة التي تصب فيها المعلومات والمهارات المكتسبة من مختلف المقررات الأكاديية والتزبوية والنفسية

(الطوالبة,2009: 25)

وفي هذه المدة يتعرض الطالب/ المطبق على أهم متطلبات هنة التدريس ويكتسب من طريقها فكرة عامة عن خصائص التعليم الناحج، وأبرز طرائت التدريس واستعحال الوسائل التعلمية التي تصادفه في أثناء عمله مع تلامذته، وينعرف كذلك على نظام المدرسة، وعلى كيفية الإثراف على هذا النظام (أبو

شعيرة، 2013: 11 ) - (11) وقد أثبتت نتائج البحوث المرتبطة بالتربية العملية أن الطلبة المطبقين يرجعون كفاءتهم في التدريس لخبراتهم المباشرة في التربية العمليّة، وتشير أيضاً إلى أن الطلبة المطبقين عادةً ما يحتفظون بخبرات التربية العملية في أعقاب تخرجمم وأن هذه الخبرات تؤثر في سلوكيات المعلم المستقبلية في حجرة الصف الدراسي (بدوي،

(356: 2011

وتعد التببة العملية الجانب الاساسي في الاعداد المهني للطالب/ المطبق حيث يكتسب اثناءها المهارات, والإجراءات التدريسية الفعلية.(حلد,2005: 169) أن نجاح عملية التربية أو فشلها، يعتمد على المعلم الذي اختار التربية كهنة له، وما يترتب على هذه المهنة من أعباء ومسؤوليات، وبكل ما تتطلبه هذه المهنة من المقومات الأساسية اللازمة لإعداد المعلم ووصوله إلى درجة الكفاية التي تجعله

قادراً على تحمل مسؤولياته والقيام بواجباته.(الخطيب,2008: 63) وتكمن أهمية التربية العملية من أهمية الأهداف التي تسعى إلى تحقيقها وبلوغها, وهي تقضي على الفجوة بين النظرية والتطبيق وتنسجم مع الاتجاهات التربوية المعاصرة في عملية إعداد وتدريب المعلمين, وتكمن أهميها بجيث إنها ججر الزاوية في برنامج إعداد المعلم وتأهيله للمهنة التدريسية واكتساب الطالب المطبق للمهارات

بشكل تدريبي ومنظم بصورة أفضل.(حادنة وعبيدات,2012: 168) كما تعد التربية العملية الفرصة الحتيقية للطالب المطبق؛ لاكتساب خبرة التدريس تحت إشراف مشرف متخصص وتوجيه ويستخدم أحدث الأدوات والأساليب

العلمية لملاحظة الندريس وتعديل سلوك الطالب المطبق.(نورالدين,2002: 1)
لكونه عصب المهنة ومحركها الأساسي، فهو المسؤول الأول عن تحقيق أهداف التربية، وعامل من عوامل تطوير الجمتمع وتنميته.( درويش,2002: 235) ولماكان المعلم مفتاح العملية التعليمية، ورائد المجتع الذي يعتمد عليه في تنشئة أبنائه النشأة القوية الصحيحة، فقد شغلت مسألة إعداده وتأهليه أذهان التزبويين والمتخصصين، ولم يعد المعلم ناقلاً للمعرفة فقط بل تقع عليه تربية الأجيال تربية عقلية وخلقية وجسمية، فضلاً عن تحقيق الأهداف التعلمية وترجمتها إلى واقع

ملموس من طريق السلوك الصحيح ( زاير وآخرون,2011: 57 ) فالمعلم يعد من أهم مدخلات العملية التعليمة التعلمية وأخطرها أثرا في إعداد وتربية النشء، وهو أحد العوامل الفاعلة في تحديد نوعية مستقبل الاجيال (الصغير،2009: 229) لذا فإن دوره لم يعد يقتصر على تقديم المعلومات المقررة في المنهج للطلبة ومطالبتهم بكفظها واسترجاعها في أثناء الاختبارات بل يمتد إلى بناء شخصيته على أسس علمية سلمة وتشجيعهم على التعلم النافع لم ولمجتمعهم (خليفات, 2013: 60) ن

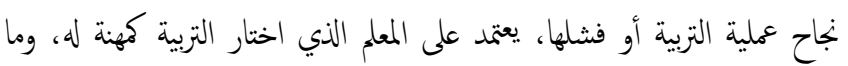
يتزتب على هذه المهنة من أعباء ومسؤوليات، وبكل ما تتطلبه هذه المهنة من المقومات الأساسية اللازمة لإعداد المعلم ووصوله إلى درجة الكفاية التي تجعله قادراً على تحمل مسؤولياته والقيام بواجباته.(الخطيب, 2008: 63)

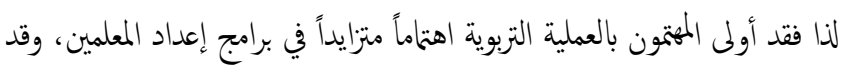
أدى هذا الاهتمام، بأن يقوم الباحثون والدارسون بدراسة برامج التدريب من جوانبه جميعها، والبحث عن العوامل الموثز فيها، والعمل على تسينها، وأن لهذا الاهتام ما يبرره، نظراً لمكانة التدريب في العملية التبوية، إذ يعد عنصراً من عناصر نجاحا. (عبيدات,2007: 201) تعد التربية العملية من أهم الأساليب في تدريب المعلمين، حيث أن الطالب في هذه المدة ينتقل من الدراسة النظرية إلى الدراسة العملية ، كما أن التربية العملية تتتلف باختلاف صيغ إعداد المعلمين حيث يقوم طلبة كلية التربية ووفقاً للنظام التنابعي على تنفيذ التربية العملية في المدارس الإعدادية لمدة ثلاثة أسابيع متصلة ويوماً من كل أسبوع خلال النصف الأول من السنة الدراسية في بعض الانظمة العربية في الغالب ، ونغس الثيء يتم في الفصل الدراسي الثاني في المدارس الثانوية. وبهذا يصل ما يخصص للندريب بين (10- 11) ساعة أسبوعياً بين التدريب المتصل والموزع، أما الكليات النكملية فيقضي فيها الطالب (14) أسبوعاً 
ومن هنا فالتربية العملية أبّاً كانت صيغتها التنظمية والتطبيقة، فإنها تشكل عنصراً 6. تحديد المصطلحات

لا غنى عنه في أي مناجج إعداد المعلمين، ومن دونها فإن هذه المناجج تفقد قيمها 1.6 التربية العملية: Teaching Practic وصلاحيتها العامة، وتعد من الوبجة التربوية ناقصة وغير بناءة (كنعان 1.1.6 عساس (1994) بانها

"احد جوانب الإعداد التزبوي، ويخصص لها فترة زمنية محددة لإتاحة فرصة للطلاب المطبقين لتطبيق ما درسوه نظرياً من المقررات الأكاديمة والثقافية والتربوية بصورة عملية في المدارس (عساس,1994: 11)

2.1.6 محود (2004) بأهها

"مجموعة من الأنشطة التي يقوم بها طلاب كليات التربية ومعاهد إعداد المعلمين، وذلك من خلال احتكاكهم المباشر بالتلاميذ في المدارس التي يختارها مشرفوهم، فيتدربوا فيها, ليكتسبوا المهارات اللازمة لمهنة التدريس".(محود، 2004: 24)

\section{1 .6 حوالة ومحمد (2005) بأنها}

"هي برنامج تدريبي علمي تقدمه كليات التربية (اعداد المعلمبن) على مدى فترة زمنية محددة وتحت إثرافها، حيث ههدف هذا البرنامج إلى إناحة الفرصة للطلاب المطبقين لتطبيق ما تعلموه من معلومات وأفكار ومفاهيم نظرية، تطبيقًا عملياً في أثناء قياهم بهام الندريس الفعلي في المدرسة، الأمر الذي يعمل على تحقيق الألفة بينهم وبين العناصر البشرية والمادية للعملية التعلمية من جهة، كما يعمل على إكسابهم الخبرات التربوية المتنوعة الجوانب المهارية والانعالية من جهة أخرى".)

$$
\begin{aligned}
& \text { حوالة ومحد,2005: 120) } \\
& 2.6 \text { الطالب/ المطبق: } \\
& \text { 1.2.6 الهاشل وممد (1990) بأنه: }
\end{aligned}
$$

"وهو طالب كلية التربية المسجل في مقرر التربية العملية والذي يقوم بالتدريب في مدارس النعليم العام, ويعتبر كأحد المدرسين في المدرسة من حيث الالتزام بالأعمال والواجبات الملقاة على عاتق المدرسين".(الهاشل ومحد,1990: 18) 2.2.6 براون (2005) بأنهُ: "معلم تحت الاعداد في المؤسسات التربوية التي تقوم بإعداد المعلمين متوق تخرجه حاصل على مؤهل تربوي يكتسب خبرات وهمارات تدريسية بإشراف وتوجيه مختصين".(براون,2005: 139)
وآخرون,2010:

$$
\text { وتكمن أهمية البحث في الجوانب الآتية: - مكت }
$$

يعد البحث محاولة للتعرف على تقويم تنفيذ برنامج التزبية العملية في مدارس التعلم الأساسي من وبجة نظر الطلبة المطبقين لدى عينة البحث.

$$
\text { يعتبر انطلاقًا لبحوث مستقبلية في هذا التجاه. }
$$

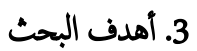

مهدف البحث الحالي التعرف على تقويم تنفيذ برنامج التربية العملية في مدارس التعلم الأساسي من وجحة نظر الطلبة المطبقين ومن خلال الإجابة عن الأسئة

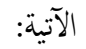

س1/ ما تقويم تنفيذ برنامج التربية العملية في مدارس التعلم الأساسي من وبحة نظر الطلبة المطبقين - ا؟ س2/ هل هناك فرق ذو دلالة احصائية ولمستوى دلالة (0.05) بين درجات وبهتي (ذكور والإناث) في تقويم تنفيذ برنامج التربية العملية في

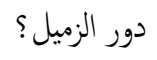
س3/ هل هناك فرق ذو دلالة احصائية ولمستوى دلالة (0.05) بين درجات وبتهي (ذكور والإناث) في تقويم تنفيذ برنامج التربية العملية في

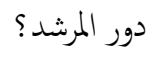
س4/ هل هناك فرق ذو دلالة احصائية ولمستوى دلالة (0.05) بين درجات وبهتي (ذكور والإناث) في تقوبم تنفيذ برنامج التربية العملية في

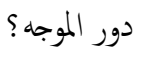
س5/ هل هناك فرق ذو دلالة احصائية ولمستوى دلالة (0.05) بين درجات وبهتي (ذكور والإناث) في تقويم تنفيذ برنامج التزبية العملية كلك؟

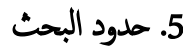

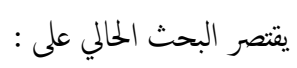

طلبة المرحلة الرابعة قسم الاجتماعيات في كلية التربية الاساسية جامعة دهوك لمسنة الدراسية (2018- 2019). 


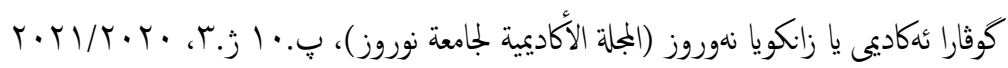

تنمية قدرة الطالب المطبق على النقد والنقد الذاتي وتقبل آراء

7.

الآخرين.(1الامد,2005: 143)

-

مساعدة الطالب / المطبق لتحقيق أدواره بوصفه معلماً.

1.1.7 أهداف التربية العملية:

قدرة المعلم على تحفيز زملائه المتدربين نخو العمل التربوي واتقانه.(الهاثني

والعزاوي, 2009: 249)

2.1.7 أهية الترية العملية

تتجلى أهمية التربية العملية على اعتبارها حجر الزاوية في برامج إعداد المعلمين في الميه النقاط التالية:

تهيئة الفرصة أمام الطالب/ المطبق لترجة المعارف والنظريات والأفكار التربوية إلى مواقق تدريسية عملية وبالتالي الربط بين الدراسة النظرية

والواقع التطبيقي.

إتاحة الفرصة أمام الطالب/ المطبق للنعرف قدراته الناتية وكفاياته التدريسية , وكذلك توفير التغذية الراجعة له.

إتاحة الفرصة أمام الطالب/ المطبق لامثلاك الكفايات العملية اللازمة لمعلم المجال ومعلم الصف وبخاصة تلك التي ترتبط بأساليب التدريس واستخدام الوسائل التعليمة وإدارة الصفوف والتعامل باييجابية مع عناصر العملية

يعمل برامج التربية العملية على توفير الفرصة أمام الطالب / المطبق لمشاهدة نماذج مختلفة من موقف التدريس وإشعاره بالثقة بنفسه في أثناء

موابحته للمواقف النعلمية.(الخطايبة وحمد,2002: 15- 16)

تكين الطالب/ المطبق من اكتساب مجموعة من المعلومات وصقل المهارات لديه والاتجاهات, لأجل أن يستفيد منها مستقبلاً في منة التعليم، لموابجة الصعوبات في المواقف النعلمية المختلفة.

تطبيق ما تعلمه الطالب/ المطبق من مبادىء تتعلق بالعملية التعليمة

التعلمية.

إتقان مهارات التدريس مثل: التخطيط والتهيد للدرس واختيار الوسائل

التعلمية المناسبة والتعزيز المناسب وطرح الأسئلة الصفية, والإجابة عن

أسئلة الطلبة.

اختبار مدى ملائمة المبادىء النظرية والأساليب التعلمية التعلمية التي يتعلمها الطالب/ المطبق في المعهد أو الكلية التزبوية. فالتربية العملية هي إحدى الوسائل التي تساعد على تقويم المبادى النظرية التي سبق أن تعلمها الطالب المطبق, وترك ما لا ينسجم مع متطلبات الواقع.(عبدلله,2004: 99) تمكين الطالب/المطبق من الجانب التطبيقي لمادة تخصصه. يتمكن من تهيئة الطلبة للدرس بالبيئة ذهنياً وتفسياً وربط المعلومات السابةة لدى الطلبة بالمعلومات الحالية. يتعرف الطالب/ المطبق على أهمية المناجج والكنب المدرسية التي يتعرض لها الطلبة في المدرسة.(عطية والهاشيم,2008: 210) الاسهام في بعض أوجه الانشطة المدرسية حس الميول والاستعدادات والقدرات وتحمل المسئوليات التي تقع على عاتقه.

تطبيق الطالب/ المطبق ما تعلمه من مبادئ ومغاهيم تربوية، التي تعلمها في الكلية أو المعهد، وبالتالي يكون قادراً على ربط المهارات والتجاهات الأنشطة.( محمد وحوالة,2005: 124) والمعلومات بعملية التطبيق، التي تعد أول لقاء مباشر للطالب/ المعلم بالواقع الصبر وتحمل المشكلات والمواقف المتوتزة.

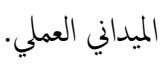
التدريب على دقة الملاحظة. معرفة القيم الأخلاقية المرتبطة بههنة التدريس وممارستها. 


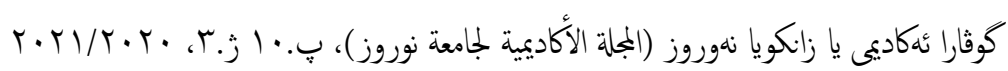

24.1.7 مارات التنفيذ

وتشمل

استخدام طرق واساليب التدريس و وسائط تعلمية مختلفة منها: التمهيد, استخدام الأسئلة , استخدام الوسائل التعليمة ,التعزيز, تنويع الحركة و الصوت, التقيد بالحصة الزمنية, تنسيق اجراءات تنفيذ الدرس.

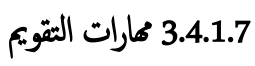

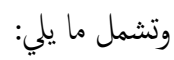

تصميم وإعداد أدوات التقو.يم الخختلفة وجميع المعلومات عن الطلبة.

تشخيص نواحي القوة والضعف في العملية التعليمة.(محمود2004: 30)

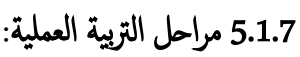

1.5.1.7 مرحلة المشاهدة:

أن مرحلة مشاهدة التطبيق يقصد بها قيام الطلبة المطبقين بمشاهدة و ملاحظة مرهام كل ما يرري حول أوجه النشاط التعليمي ملاحظة دقيقة و منظمة و موجحة نحو مشاهدة مواقف معينة يتفق عليها عضو هيئة التدريس القائم بعملية التطبيق مع الطلبة المطبقين .(الكرداني والسايح ,2002: 66)

ومن خلال ما تقدم يمكن حصر أهداف مرحلة المشاهدة في النقاط النالية: مساعدة الطالب المطبق علي التكيف مع الجو المدرسي الجديد.

إتاحة الفرصة أمام الطالب المطبق للتعرف علي الأنشطة المدرسية. إتاحة الفرصة أمام الطالب المطبق للتعرف علي أنماط متعددة من العلاقات

$$
\text { الإنسانية داخل المجتع المدرسي. }
$$

محاولة ربط ما تعلمه نظرياً في الكلية بما يلاحظه أو يشاهده أثناء حضوره

مع المعلم المتعاون خلال فترة المشاهدة. (عوض,2006 : 25) أن يتعرف الطالب/ المطبق على الأنماط السلوكية المختلفة للطلبة في المواقف

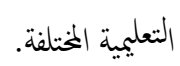

أن يتعرف الطالب/لمطبق مهارات واستخدام طرق التدريس وأساليه واستخدام الوسائل النعلمية والأنشطة التعليمة والتأكد من تحقيق الأهداف التعلمية والتعرف على نقاط القوة رالضعف من خلال التقو.م. التعرف على المشكلات التي قد يوابهها الطالب المطبق أثناء التدريس $(274: 2001,2)$.
تدريب الطالب/ المطبق على تحمل المسؤولية في التنظيم المدرسي

والمشاركة في الأنشطة التربوية والاجتاعية المختلفة دون إقتصار دوره على

التدريس فقط. (الفنلاوي,2004: 109-110)

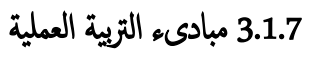

التربية العملية جزء لا يتجزأ من مواد الإعداد التربوي.

اهتمام التربية العملية بجميع أنواع الأنشطة المدرسية.

تكون التربية العملية أكثر فائدة عندما تتم في ظروف طبيعية بعيدة عن

التصنع.

تأخذ التربية العملية بعين الاعتبار الفروق الفردية بين الطلاب المعلم.

تقويم الطلاب المعلمين ركن أساسي من أركان التربية العملية.

التربية العملية عملية تعاونية يسهم في الإشراف عليها أكثر من

طرف.(عبدالله,2004: 86-96)

يتطلب نجاح برنامج التربية العملية توافر مجموعة من الإمكانات البشرية

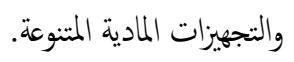

ينبغي أن تكون أهداف برنامج التربية العملية واضحة للمشتركين في

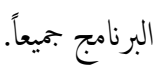

هينغي أن يقوم برنامج التربية العملية على أسس تربوية تراعي فهيا التجديدات جميعاً والمتغيرات التزبوية في مجال إعداد المعلمين.(جرادات

وآخرون,2008: 17-18)

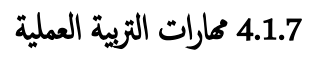

1.4.1.7 مارات التخطيط وتشمل : تحديد الخبرات السابقة للطلبة ومستوى نموهم العقلي. تحديد الوسائل والمواد التعلميمة للتدريس. تحليل محتوى المادة العلمية للدرس وتحديد محتوى التعلم. صياغة أهداف موضوع الدرس. إعداد استراتيجية لتحقيق أهداف التعلم. 


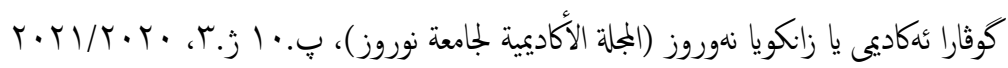

\section{تهيئة التلاميذ قبل بداية الدرس جسمياً وعقلية ونفسياً.}

اختيار الوسيلة التعليمة المناسبة للحصة بحيث تكون مرتبطة بموضوع الدرس ومثيرة لإنتباه التلاميذ صادقة المعلومات ومناسبة لأعار وخبرات الطلبة بجيث تزيد قدرة التلاميذ على التأمل و الملاحظة.(عوض,

$(2006: 27$

2.7

1.2.7 دراسة أبو شندي وآخرون (2009): (تقويم برنامج التربية العملية في

\section{جامعة الزرقاء الخاصة ومقترحات تطويره)}

هدفت هذه الدراسة إلى تقوبم برنامج التربية العملية في جامعة الزرقاء الخاصة ومقترحات تطويره, تكونت عينة البحث من (96) طالبًا وطالبة تم اختيارهم بالطريقة القصدية، ولتحقيق أهداف البحث أعد الباحثون استبانة مكونة من (59) فقرة تم التحقق من صدقها وثباتها, وقد استعمل الباحثون الوسائل الإحصائية الآتية: معادلة (ألفا كرونباخ)، معامل الارتباط بيرسون، معادلة (سبيرمان براون)، الوسط الحسابي الفرضي، اختبار (ت)، تحليل التباين

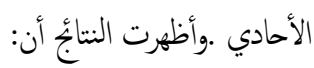

تقويم الطلبة لمجلات برنامج التربية العملية كان على النحو النالي: احتل مجال تقو.يم مشرف التربية العملية (المشرف التربوي) المرتبة الأولى، فالمعلم المتعاون، ثم إجراءات برنامج التربية العملية، فالمدرسة المتعاونة، وأخيراً

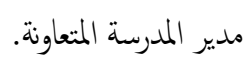

كما أظهرت النتابُج عدم وجود فروق ذات دلالة إحصائية عند مستوى دلالة (0.05) في تقويم الطلبة/ المعلمين لبرنامج التربية العملية، تعزى إلى

$$
\text { جنس الطالب/ المعلم والمعدل التراكي ككل. }
$$

أما بالنسبة لمنطقة الندريب فقد أظهرت الدراسة فروقاً ذات دلالة إحصائية في تقويم الطلبة لمجال مدير المدرسة المتعاونة، ولم يكن لها تأثير في باقي

المجالات.

2.2.7 دراسة الفقعاوي (2011): (تقويم برامج التربية العملية لإعداد معلم التعليم الأساسي بكليات التربية في جامعات قطاع غزة) هدفت الدراسة التعرف إلى مدى توافر معايير تقويم برامج التربية العملية لإعداد معلم التعليم الأساسي بكليات التربية في جامعات قطاع غزة في الإعداد النظري والعملي من طريق الإجابة عن أسئلة، وتكونت عينة الدراسة من (279) طالباً
2.5.1.7 مرحلة المشاركة (مرحلة الثدريس الفعلي):

هي المرحلة التي تكون بعد مرحلة المشاهدات و مرحلة التدريب على التدريس حيث أن هذه المرحلة تكون داخل مؤسسة التربص بجيث تعتبر أولى خطوة يتم فيها الاتصال المباشر بين التلاميذ والطالب المطبق يقوم فهيا بأداء مختلف المهام الندريسية، وتعتبر هذه المرحلة كاختبار للطالب المطبق لما اكتسبه نظريا وتطبيقيا ومقارنته وتطبيقه في أرض الواقع وفق شروط و أهداف منظمة مسبقا بمشاركة الأستاذ المتعاون بمؤسة التربص، ويرى الباحث أن مرحلة التدريس الفعلي تتم

في بخطوتين أساسيتين هها:

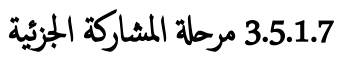

قبل أن يبدأ الطالب المطبق في التدريس الفعلي التلاميذ ويتحمل مسؤولياته النعلمية لدرس كامل يككن أن يعهد للطالب المطبق بتنفيذ بعض هذه المهام بمشاركة المعلم الأساسي له مما يجعله أقل توترا وحتى يتعود على مسؤوليات اعداد وإخراج الدرس. (السعيد وآخرون, 2016 : 170) يقوم الطالب المطبق في هذه المرحلة من تنفيذ موقف تعليمي محدد مخطط له

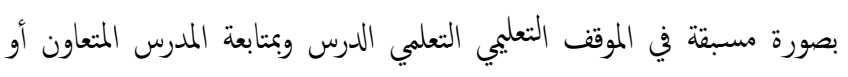

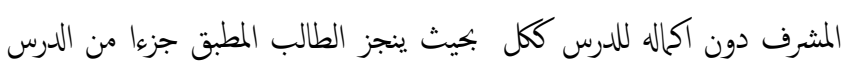
والباقي يكمال المعلم المتعاون.(خطايبة, 2002 : 95)

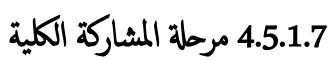
وتعد هذه المرحلة من أهم المراحل في برنامج التربية العملية الميدانية، حيث يتحمل الطالب/ المطبق مسؤولية تنفيذ جميع المهام والنشاطات التعلمية التي يتطلبها الموقف التعليمي، وهنا يجب على الطالب المطبق أن يكون متتلكا لميع الخبرات والمهارات والكفايات التدريسية الأساسية من أجل القيام بالتدريس الفعلي بعرده. (عوض, 2006: 27) وهناك شروط ينبني مراعانها في مرحلة المشاركة الكلية نذكر منها: أن لا يقوم الطالب المطبق بالتدريس الا بعد أن يكون قد أعد درسه بصورة جيدة وذلك بإشراف مدرس الكلية والمعلم المتعاون. أن تتم عملية الندريس تحت إثراف مدرس الكلية أو المعلم المتعاون. أن يكون هنا تقويم لكل حصة يدرسها الطالب المطبق, حيث يشترك في هذه العملية مدرس الكلية والمدرس المتعاون والطلبة المطبقين.(حسن,

(240: 2004 


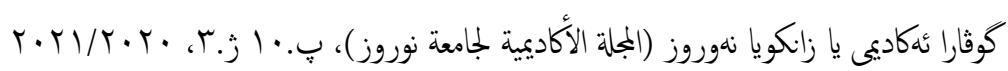

عدم وجود فروق دالة إحصائياً في تقديرات الطلاب المعلمين لواقع التربية العملية في جامعة القدس المفتوحة تعزى لمتغيرات الجنس والحالة الاجتاعية

والتخصص.

3.7 - (3وانب الإفادة من الدراسات السابقة:

$$
\text { تحديد مشكلة البحث. }
$$

الوسائل الإحصائية التي تلائ الدراسة.

اعداد أداة البحث.

$$
\text { تفسير النتائُ }
$$

\section{7 منهجية البحث واجراءاته}

تتضمن منهية البحث وصفاً لمجتع البحث وطريقة اختيار العينة ووصف أداة البحث واجراءات صدقها وثباتها وتطبيق الأداة والوسائل الإحصائية المستخدمة

$$
\text { لتحليل البيانات. }
$$

\subsection{7 بجمع البحث}

تكون مجتع البحث من طلبة قسم الاجتاعيات كلية التربية الأساسية المرحلة الرابعة البالغ عددم (106 ) طالب وطالبة بواقع (54) طالباً و ( 52 ) وطالبة

$$
\text { للدراسات الصباحية للسنة الدراسية (2018-2019). }
$$

\subsection{7 عينة البحث}

بعد تحديد مجتمع البحث من طلبة قسم الاجتاعيات كلية التربية الأساسية اجامعة دهوك قصدياً من أقسام الكلية , تم اختيار (60) طالباً وطالبة بواقع

$$
\text { (35) طالباً و( 25) طالبة من طلبة المرحلة الرابعة وبنسبة (57\%). }
$$

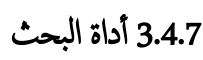

$$
\text { 1.3.4.7 وصف الأداة }
$$

أعتمدت الباحثة في تقوبم تنفيذ برنامج التزبية العملية في مدارس التعلم الأساسي من وبحة نظر الطلبة المطبقين على استبانة أعدتها الباحثة والتي تكونت من (33) فقرة موزعة على ثلاث بدائل وهي بدرجة ( كيبرة, متوسطة, قليلة). وأعطت الباحثة الأوزان (1,2,3) للبدائل بدرجة (كبيرة, متوسطة, قليلة) على التوالي في ضوء ذلك تم تمع درجات الإجابة عن كل الفقرات المكون من (33) فقرة وكانت اعلى درجة (99) وأدنى درجة (33) والوسط الفرضي (66) درجة.
وطالبة من طلاب الجامعات في قطاع غزة (الأزهر الإسلامية الأقصى القدس المفتوحة)، تم اختيارهم بالطريقة العشوائية الطبقية بحسب الجنس والجامعة والتخصص, وقامت الباحثة بإعداد استبانتين لثقويم برنامج التربية العملية من الناحيتين النظرية والعملية، .واستخدمت الباحثة الأساليب الإحصائية التالية اختبار " ت " وتحليل التباين الأحادي، واختبار شيفيه. وأظهرت النتائج أن: تقديرات الطلبة لبرامج التربية العملية كانت متوسطة في كافة مجالات أداة الدراسة. عدم وجود فروق دالة إحصائياً في تقديرات الطلبة لواقع برامج التربية العملية تعزى لمتغيري الجنس والتخصص.

\subsection{7 دراسة الغيشان والعبادي (2013): (تقويم برنامج التربية العملية في جامعة}

الزيتونة الأردنية الخاصة من وبحة نظر الطلاب) هدفت الدراسة إلى تقويم برنامج التربية العملية في جامعة الزيتونة الأردنية الخاصة من وبحة نظر الطلاب. وتكونت عينة البحث من (147) طالباً وطالبة, وقد استخدم الباحثان استبانة مكونة من(40) فقرة تتناول الجمالات التالية: المشرف

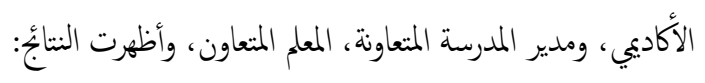
أن تقديرات الطلاب لواقع برنامج التربية العملية بجامعة الزيتونة الأردنية الخاصة كانت متوسطة على الدرجة الكلية لجلالات أداة الدراسة. ولم تظهر الدراسة فروقاً دالة إحصائياً في تقديرات الطلاب التقويمة لبرنامج التربية العملية تعزى لمتغيري الجنس والتخصص.

4.2.7 دراسة شاهين (2014)

(تقويم برنامج التربية العملية في جامعة القدس المفتوحة من وجهة نظر الطلبة المعلمين) دراسة هدفت إلى تقويم برنامج التزبية العملية في جامعة القدس المفتوحة من وبجمة نظر الطلبة المعلمين. تكونت عينة الدراسة من (389) طالباً وطالبة، واستخدم

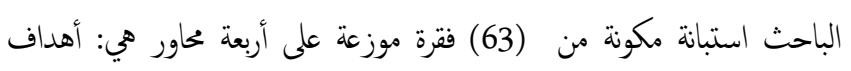
البرنامج وخطواته، إدارة المدرسة المتعاونة، المعلم المتعاون، المشرف الأكاديمي.

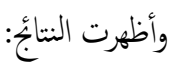
أن تقديرات الطلاب لواقع التربية العملية بجامعة القدس المفتوحة كانت 


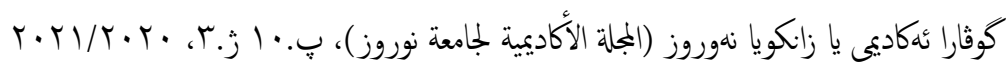

اختبار (t.test) لعينتين مستقلتين وذلك باستخدام برنامج (spss).

\section{7 عرض/النتائ/وتفسيرها}

بعد جمع البيانات من افراد عينة البحث وتحليلها إحصائيا وفقًا لأسئلة البحث، ستعرض الباحثة نتائج البحث وعلى النحو الأتي:

7.7 النتاجُ المتعلقة بالسؤال الأول

"ما تقويم تنفيذ برنامج التربية العملية في مدارس التعلم الأساسي من وبجة نظر الطلبة المطبقين تبعاً لمتغير الجنس

وللإجابة عن السؤال استخرجت الباحثة حدة كل فقرة والوزن النسبي, وكما

$$
\text { موضح في الجدول (1,2,3,4,5,6) . }
$$

جدول 1. درجة حدة الفقرات والوزن النسبي لفقرات الأداة لعينة الذكرر(الطلاب) اللمجال/دور الزميل

\begin{tabular}{|c|c|c|c|c|}
\hline 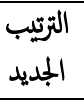 & 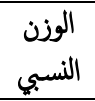 & الحدة & الجمال الأول/ دور الزميل & ت \\
\hline 4 & 77 & 2.31 & يتعامل معي كساعد في شرح المادة & 1 \\
\hline 2 & 82.66 & 2.48 & 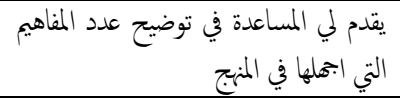 & 2 \\
\hline 8 & 67.33 & 2.02 & تيقدم لي الدي الاقتراحات البناءة من أجل & 3 \\
\hline 7 & 68.33 & 2.05 & يساعدني على التوافق المهني & 4 \\
\hline 8 & 67.33 & 2.02 & يوفر لي بيئة صفية مناسبة & 5 \\
\hline 1 & 93.33 & 2.8 & التطبيق لي المواد التعلميمة اللازمة أثناء & 6 \\
\hline 7 & 68.33 & 2.05 & يشجعني في ادارة الصف بشكل جيد & 7 \\
\hline 5 & 75 & 2.25 & يعزز محاولاتي الإيجابية أثناء التدريس & 8 \\
\hline 6 & 74 & 2.22 & يوضح لي الواجبات الموكلة إلي & 9 \\
\hline 3 & 78 & 2.34 & يساعد في التعبير عن أفكاري وآرائي & 10 \\
\hline & 75.131 & 2.254 & الكلي & \\
\hline
\end{tabular}

يتضح من الجدول (1) ان جميع القيم بلغت نسبتها أكثر من المتوسط الفرضي البالخ (66) درجة للأداة ككل, وهذا يعني ان تقويم تنفيذ برنامج التربية العملية في مدارس التعلم الأساسي من وبجة نظر الطلبة المطبقين تبعاً لمتغير الجنس ككل قد وفروا المواد التعلمية اللازمة أثناء التطبيق وقدموا لمم المساعدة في توضيح عدد المفاهيم التي يجهلها الطلبة المعلمين في المنجج و ساعدوهي في التعبير عن أفكارهي وآرائه و كان تعاملهم كساعد في شرح المادة مما يعزز محاولاتي الإيمابية أثناء التدريس و يوضح لمم الواجبات الموكلة إليهم و يساعدونهم على التوافق المهني ويشجعهم في ادارة الصف بشكل جيد ويقدم لمم الاقتراحات البناوة من أجل تحضير الدروس بدقة فضلاً عن توفير بيئة صفية مناسبة هذا حسب وبجة نظر

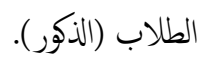

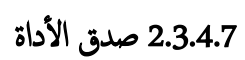

لغرض استخراج الصدق الظاهري تم عرض الأداة على مجموعة من المحكمين الختصين في مجال العلوم التربوية والنفسية من ذوي الخبرة والاختصاص وذلك لإبداء آرائهم ومقترهاتهم على فقرات المقياس , وبناءاً عليه تم قبول جميع الفقرات, كما تم إجراء النعديلات اللغوية على عدد من الفترات على وفق اقتراحات السادة المكمين لتناسب هدف البحث. وقد أعتمدت الباحثة نسة (80\%) فأكثر من آراء المحكمين معياراً لدى اتفاق آراء الخبراء المحكمين للمقياس.

3.3.4.7 ثبات الأداة وقد استخدمت الباحثة طريقة إعادة الاختبار لاستخراج الثبات لأداة البحث، إذ طبقت المقياس على عينة مكونة من (40) طالباً وطالبة من طلبة المرحلة الرابعة في قسم الاجتاعيات يوم الثلاثاء الموافق ( 2019/4/16) وجرت الإعادة يوم الأحد الموافق (2019/5/5) وبعد ذلك حسب معامل ارتباط بيرسون بين درجات الطلبة في التطبيق وقد بلغ (83\%) وبذلك ثم التحقق من ثبات المقياس.

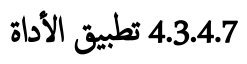

طبقت الباحثة المقياس بالصورة النهائية على أفراد عينة البحث المكونة من (60) طالباً وطالبة من قسم الاجتاعيات المرحاة الرابعة, وعند توزيع المقياس على الطلبة طلب منهم الإجابة على نفس ورقة المقياس وذلك بالتأشير على البديل الذي يناسب وبجة نظرهم لتحقيق هدف البحث مع حرصهم الإجابة على جميع الفقرات دون ترك أي فقرة وكانت مدة التطبيق الموافق يوم الأربعاء

(2019/5/8)

\subsubsection{7 تصحيح الأداة}

أعتمدت الباحثة في تصحيح الأداة على اعطاء الأوزان (1,2,3) للبدائل بدرجة (كيبرة ومتوسطة وقليلة) على التوالي في ضوء ذلك تم جمع درجات الإجابة عن كل الفقرات المكون من (33) فقرة وكانت الدرجة تتراوح بين ( 99-33).

5.7 الوسائل الوحصائية

أعتمدت الباحثة الوسائل الاحصائية الآتية:

معامل ارتباط بيرسون Pearson: لإيجاد ثبات مقياس تطبيق

(البياتي،2008: 140)

المتوسط الحسابي: لإيجاد التميزية بين الفقرات (المنيزل وعايش،2006: 


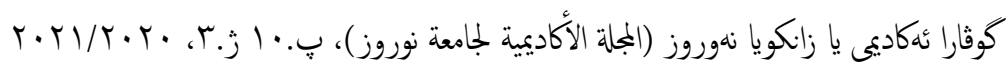

علاقات جيدة مع المتعلمين فضلاً عن ارشاده إلى كيفية زيادة الثقة بالنفس لدههم هذا حسب وبحة نظر الطلاب (الذكور). تعزي الباحثة هذه النتيجة إلى ان المدرسين والمدرسات كان لهم دوراً إيجابياً وذلك لشعورهم ان الطلبة المطبقين سيكون زملاء لم مستقبلاً, وان من أخلاقيات المهنة مساعدة من يجتاج إلى المعلومة هذا من جانب ومن جانب آخر ان المدرسين والمدرسات يمتلكون حساً وطنياً وذلك لمساعدة الطلبة المطبقين على أن

يكونون أفضل علمياً مستقبلاً. جدول (3) درجة حدة الفقرات والوزن النسبي لفقرات الأداة لعينة الذكرر(الطلاب) للمجال/

\begin{tabular}{|c|c|c|c|c|}
\hline \multicolumn{5}{|c|}{ دور الموجه } \\
\hline التزيب & الوزن & ل د رجة & المجال الثالث/ دور الموجه & ت \\
\hline الجديد الجد & النسبي & المدة الحدة & & \\
\hline 4 & 70.33 & 2.11 & المختلفني إلى معرفة خصائص الطلبة & 1 \\
\hline 1 & 87.33 & 2.62 & يوجهني إلى معرفة المرافق المدرسية & 2 \\
\hline 6 & 64.66 & 1.94 & يوجهني إلى كيفية جذب انتباه الطلبة & 3 \\
\hline 5 & 69.33 & 2.08 & للتئهني إلى كيفية زيادة دافعية الطلبة & 4 \\
\hline 7 & 63.66 & 1.91 & التطويريز الذاتي كيفية اكتساب مكارات & 5 \\
\hline 2 & 79 & 2.37 & تيونهيذها إلى تصحيح خطط الدرس قبل & 6 \\
\hline 3 & 73.33 & 2.2 & يعلمني كيفية انتقاء المعلومات العلمية & 7 \\
\hline 9 & 54 & 1.62 & 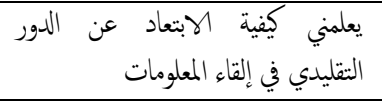 & 8 \\
\hline 10 & 51.33 & 1.54 & يوبهني إلى اكتشاف حقائق العلم & 9 \\
\hline 8 & 55 & 1.65 & جويودة التعلم إلى كيفية التدريس على وفق & 10 \\
\hline & 66.797 & 2.004 & 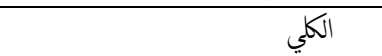 & \\
\hline
\end{tabular}

يتضح من الجدول (3) ان بضع فقرات المقياس سبلت نسبها أكثر من المتوسط الفرضي البالغ (66) درجة للأداة ككل, وهذا يعني ان تقويم تنفيذ برنامج التربية العملية في مدارس التعلم الأساسي من وبجة نظر الطلبة المطبقين تبعاً لمتغير الجنس ككل عدا الفقرات (3,5,8,9,10) على التوالي وسجلت قيم متقاربة إلى حد ما من المتوسط الحسابي كلها مؤشراً على ضعف دور مدرسي ومدرسات

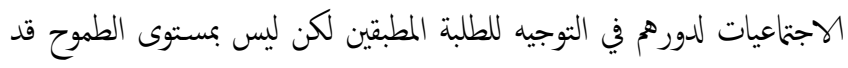
وبحوا الطلبة المعلمين إلى معرفة المرافق المدرسية وكذلك كانوا يوجهمه إلى تصحيح خطط الدرس قبل تنفيذها و يعلمهم كيفية انتقاء المعلومات العلمية و يوبجهم إلى معرفة خصائص الطلبة الخختلفة وكذلك قلة توبجمم إلى كفية زيادة دافعية الطلبة التعلم وأيضاً يوجثم إلى كفية جذب انتباه الطلبة وضعف يوجهمه إلى كيفية
تعزي الباحثة هذه النتيجة إلى ان المدرسين والمدرسات كان لم دوراً إيجابياً وذلك لشعوره ان الطلبة المطبقين سيكون زملاء لمم مستقبلاً, وان من أخلاقيات المهنة مساعدة من يحتاج إلى المعلومة هذا من جانب ومن جانب آخر ان المدرسين والمدرسات يمتلكون حساً وطنياً وذلك لمساعدة الطلبة المطبقين على أن يكونون أفضل علمياً مستقبلاً. جدول (2) درجة حدة الفقرات والوزن النسبي لفقرات الأداة لعينة الذكرر(الطلاب) للمجال/ دور المرشد

\begin{tabular}{|c|c|c|c|c|}
\hline الجيد الجيد & الوزن النسب & المدة & المجال الثاني/ دور المرثد & 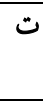 \\
\hline 4 & 73.33 & 2.2 & يرشدني إلى مصادر المعرفة & 1 \\
\hline 3 & 77 & 2.31 & يرشدني إلى التعامل الانساني مع الطلبة & 2 \\
\hline 5 & 72.33 & 2.17 & ينصحني بتذليل صعوبات المادة العلمية & 3 \\
\hline 2 & 80.66 & 2.42 & يرشدرني إلى معرفة طبيعة المنهج الذي & 4 \\
\hline 4 & 73.33 & 2.2 & يوضح لي أخلاقيات حهنة التدريس & 5 \\
\hline 10 & 61.66 & 1.85 & يرشدني إلى الابتعاد عن الروتين & 6 \\
\hline 6 & 71.33 & 2.14 & تحتصني العلم كيفية ترتيب عملي للوصول إلى & 7 \\
\hline 10 & 61.66 & 1.85 & ينصحني بإقامة علاقات جيدة مع المتعلمين & 8 \\
\hline 11 & 58 & 1.74 & يرشدني إلى كيفية زيادة الثقة بالنفس & 9 \\
\hline 7 & 70.33 & 2.11 & ينصحني بكيفية التعامل مع البيئة التعليمية & 10 \\
\hline 9 & 65.66 & 1.97 & ينصحني بالابتعاد عن السجالات غير & 11 \\
\hline 1 & 82.66 & 2.48 & يرشدني إلى التعليمات والضوابط المدرسية & 12 \\
\hline 8 & 69.33 & 2.08 & ينصحني التمكن من وسائل الاتصال & 13 \\
\hline & 70.56 & 2.116 & الكلي & \\
\hline
\end{tabular}

يتضح من الجدول (2) ان أغلب القيم بلغت نستها أكثر من المتوسط الفرضي البالغ (66) درجة للأداة ككل عدا الفقرات (6,8,9) على التوالي ولكن سجلت قيم مقبولة وقريبة نوعاً ما من المتوسط الفرضي, وهذا يعني ان تقويم تنفيذ برنامج التربية العملية في مدارس التعلم الأساسي من وبجة نظر الطلبة المطبقين تبعاً لمتغير الجنس ككل قد كانوا يرشدون الطلبة المطبقين إلى التعليمات والضوابط المدرسية وكذلك كانوا يرشدونه إلى معرفة طبيعة المنهج الذي يدرسونه وأيضاً يرشدونه إلى التعامل الانساني مع الطلبة و يرشدونه إلى مصادر المعرفة و يوضح لم أخلاقيات هنة الندريس و ينصحهم بتذليل صعوبات المادة العلمية و ينصحهم بكيفة ترتيب عملهم للوصول إلى تحقيق العلم وكذلك ينصحهم بكيفية التعامل مع البيئة التعليمية و ينصحهم التمكن من وسائل الاتصال الحديثة و ينصحهم بالابتعاد عن السجالات غير المجدية و يرشدونهم إلى الابتعاد عن الروتين و ينصحهم بإقامة 


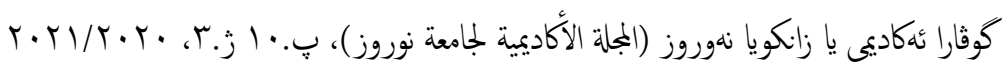

تعزي الباحثة هذه النتيجة إلى ان المدرسين والمدرسات كان لمم دوراً إيجابياً وذلك لشعورهم ان الطلبة المطبقين سيكون زملاء لمم مستقبلاً , وكان واجهيم كإنسان صاحب رسالة مقدسة أن يشجع الطالب المطبق على التحلي بأخلاق هذه

جدول (5) درجة حدة الفقرات والوزن النسبي لفقرات الأداة لعينة الكاث (الطالبات) اللمجال/دور المرشد

\begin{tabular}{|c|c|c|c|c|}
\hline الجئي & المبن الوزن & المدة & الجمال الثاني/دور المرشد & 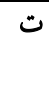 \\
\hline 4 & 77.33 & 2.32 & يرشدني إلى مصادر المعرفة & 1 \\
\hline 8 & 70.66 & 2.12 & يرشدني إلى التعامل الانساني مع & 2 \\
\hline 8 & 70.66 & 2.12 & العلمية & 3 \\
\hline 1 & 92 & 2.76 & أدرسدُ ئني إلى معرفة طبيعة المنهج الذي & 4 \\
\hline 5 & 76 & 2.28 & يوضح لي أخلاقيات كنة الندريس & 5 \\
\hline 11 & 50.66 & 1.52 & يرشدني إلى الابتعاد عن الروتين & 6 \\
\hline 6 & 74.66 & 2.24 & ينصحني بكيفية ترتيب عملي للوصول & 7 \\
\hline 9 & 62.66 & 1.88 & المتعلمين & 8 \\
\hline 10 & 58.66 & 1.76 & يرشدني إلى كيفية زيادة الثقة بالنفس & 9 \\
\hline 4 & 77.33 & 2.32 & النعلمحنية بكيفية التعامل مع البيئة & 10 \\
\hline 7 & 72 & 2.16 & الجمدية & 11 \\
\hline 2 & 90.66 & 2.72 & 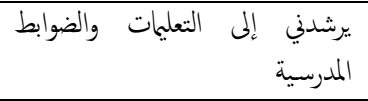 & 12 \\
\hline 3 & 81.33 & 2.44 & ينصحني التمكن من وسائل الاتصال & 13 \\
\hline & 73.431 & 2.203 & الكلي & \\
\hline
\end{tabular}

يتضح من الجدول (5) ان جميع القيم بلغت نبتها أكثر من المتوسط الفرضي البالغ (66) درجة للأداة ككل عدا الفقرات (6,8,9) على التوالي فقد بلغت نسبتها المئوية أقل نوعاً ما من المتوسط الفرضي, وهذا يعني ان ان تقويم تنفيذ برنامج التربية العملية في مدارس التعلم الأساسي من وبهة نظر الطلبة المطبقين تبعاً لمثغير الجنس ككل قد قاموا بارشاد الطلبة المطبقين إلى معرفة طبيعة المنهج الذي

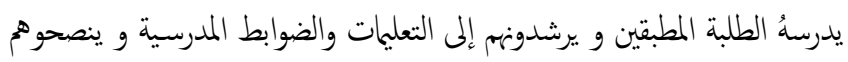
التمكن من وسائل الاتصال الحديثة و يرشدوهم إلى مصادر المعرفة و ينصحوهم

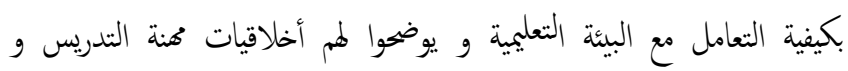
ينصحوه بكيفية ترتيب عملي للوصول إلى تحقيق العلم و ينصحوهم بالابتعاد عن السجالات غير المجدية و يرشدوهم إلى التعامل الانساني مع الطلبة و ينصحوهم
اكتساب محارات التطوير الذاتي لليهم و يوجتهم إلى كيفية الندريس على وفق جودة التعلم و يعلمهم كيفية الابتعاد عن الدور التقليدي في إلقاء المعلومات فضلاً عن قلة توجيهم إلى اكتشاف حقائق العلم هذا حسب وبجة نظر الطلاب

ترى الباحثة أن السبب في ذلك قد يعود إلى ان مدرسي ومدرسات لليهم تمسك بأخلاقيات هنة التعليم لكن ليس بالمستوى المطلوب ، حيث أن منصبه يختم عليهم التحلي بهذه الصفات وكان عليهم أن يلعبوا دوراً موجهاً أفضل ، كما أن موقعهم في العمل والصلة التي تربطهم بالطلبة المطبقين احتاجت إلى مثل هذه

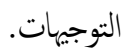

جدول (4) درجة حدة الفقرات والوزن النسبي لفقرات الأداة لعينة الاناث (الطالبات) لمجال/دور الزميل

\begin{tabular}{|c|c|c|c|c|}
\hline الجتيب & الوزن & المدة & الججال الأول/ دور الزميل & ت \\
\hline 9 & 68 & 2.04 & يتعامل معي كساعد في شرح المادة & 1 \\
\hline 2 & 85.33 & 2.56 & 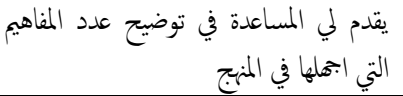 & 2 \\
\hline 8 & 72 & 2.16 & يقدم لي الاقتراحات البناءة من أجل تحضير & 3 \\
\hline 5 & 76 & 2.28 & يساعدني على التوافق المهني & 4 \\
\hline 7 & 73.33 & 2.2 & يوفر لي بيئة صفية مناسبة & 5 \\
\hline 1 & 88 & 2.64 & يوفر لي المواد التعليمية اللازمة أثناء التطبيق & 6 \\
\hline 4 & 78.66 & 2.36 & يشجعني في ادارة الصف بشكل جيد & 7 \\
\hline 6 & 74.66 & 2.24 & يعزز محاولاتي الإيبابية أثناء التدريس & 8 \\
\hline 3 & 81.33 & 2.44 & يوضح لي الواجبات الموكلة إلي & 9 \\
\hline 9 & 68 & 2.04 & يساعد في التعبير عن أفكاري وآرائي & 10 \\
\hline & 76.531 & 2.296 & الكلي & \\
\hline
\end{tabular}

يتضح من الجدول (4) ان جميع القيم بلغت نسبتها أكثر من المتوسط الفرضي البالغ (66) درجة للأداة كلل, وهذا يعني ان تقويم تنفيذ برنامج التربية العملية في

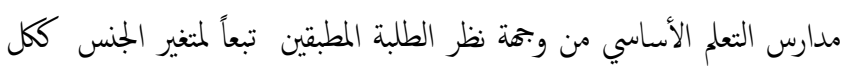
قد وفروا المواد التعلمية اللازمة أثناء التطبيق لمم و قدموا لمم المساعدة في توضيح عدد المفاهيم التي يجهلها الطلبة المطبقين في المنهج و يوضح لم الواجبات الموكلة

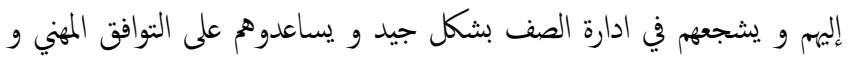
يعزز محاولاتهم الإيجابية أثناء الندريس و وفروا لم بيئة صفية مناسبة و يقدموا لمم الاقتراحات البناءة من أجل تخضير دروسهم بدقة وتعاملوا معهم كساعد في شرح المادة و ساعدوه في التعبير عن أفكارهم وآرائه هذا حسب وبحة نظر الطالبات 


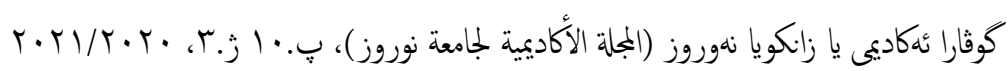

المختلفة و يوجهمه إلى اكتشاف حقائق العلم هذا حسب وبحة نظر الطالبات

تعزي الباحثة هذه النتيجة إلى ان المدرسين والمدرسات كان لهم دوراً إيجابياً نوعاً ما ولكن ليس بالشكل الذي يحقق الأهداف من عملية التربية العملية حيث قاموا ببناء علاقات شخصية معهم التي تتطلب الاحترام المتبادل بينهم. السؤال الثاني: "هل هناك فرق ذو دلالة احصائية ومستوى دلالة (0.05) بين درجات وبهتي (ذور والإناث) في تقويم تنفيذ برنامج التربية العملية في دور

الزميل؟

وللتحقيق من هذا الهدف استخرجت الباحثة المتوسط الحسابي والانراف المعياري والقيمة الثائية المحسبة والجدولية لدور الزميل كما هو موضح في الجدول

جدول (7) المتوسط الحسابي والانحراف المعياري والقمة الثائية المسوبة والجدولية لدور الزميل

\begin{tabular}{|c|c|c|c|c|c|c|}
\hline \multirow{2}{*}{ الدلالة } & \multicolumn{2}{|c|}{ القيمة التائية } & \multirow{2}{*}{ المعياري } & \multirow{2}{*}{ الحسايي } & \multirow[t]{2}{*}{ العدد } & \multirow[t]{2}{*}{ الجنس } \\
\hline & القيمة & القيمة & & & & \\
\hline 0.05 & الجدولية & المحسوبة & & & & \\
\hline غير دالة & 2.00 & 0.413 & 8.267 & 75.131 & 10 & ذكور \\
\hline احصائية & & & 6.803 & 76.531 & 10 & اناث \\
\hline
\end{tabular}

يتضح من الجدول (7) ان القيمة النائية المحسوبة قد بلغت (0.413) وهي أقل من القيمة الثائية الجدولية البالغة (2.00) وهذ يعني أنهّ لا يوجد فق ذو دلالة احصائية بين وبهتي نظر طلبة عينة البحث في دور مدرسي ومدرسات في تنفيذ برنامج

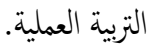

وتعزي الباحثة هذه النتيجة إلى ان الطلبة (الذكور, الاناث) أفراد عينة البحث يخضعون إلى نفس برنامج التربية العملية, فضلاً عن ذلك انهم يدرسون في نفس المدارس والتي تخضع للتعليات نفسها مع اختلاف بسيط بين المدرسين والمدرسات

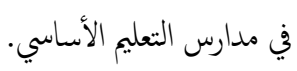
السؤال الثالث: "هل هناك فرق ذو دلالة احصائية ومستوى دلالة (0.05) بين درجات وبهتي (ذكور والإناث) في تقو.يم تنفيذ برنامج التربية العملية في دور المرشد؟" - 20 - n

وللتحقيق من هذا الهدف استخرجت الباحثة المتوسط الحسابي والانراف المعياري والتيمة الثائية المسوبة والجدولية لدور المرشد الزميل كما هو موضح في لهي

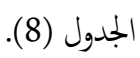

بتذليل صعوبات المادة العلمية و ينصحوهم بإقامة علاقات جيدة مع المتعلمين و يرشدوه إلى كيفية زيادة الثقة بالنفس فضلاً عن ارشاده إلى الابتعاد عن الروتين هذا حسب وبهة نظر الطالبات (1الاناث). تعزي الباحثة هذه النتيجة إلى ان المدرسين والمدرسات كان لم دوراً إيجابياً وذلك لشعورهم ان الطلبة المطبقين سيكون زملاء لهم مستقبلاً فهذا يدل على أهمية تمسك المعلم بأخلاقيات المهنة والتحلي بها وأهها الشعور بالأمن والثقة والاحترام المتبادل.

جدول (6) درجة حدة الفقرات والوزن النسبي لفقرات الأداة لعينة الكاث (الطالبات)

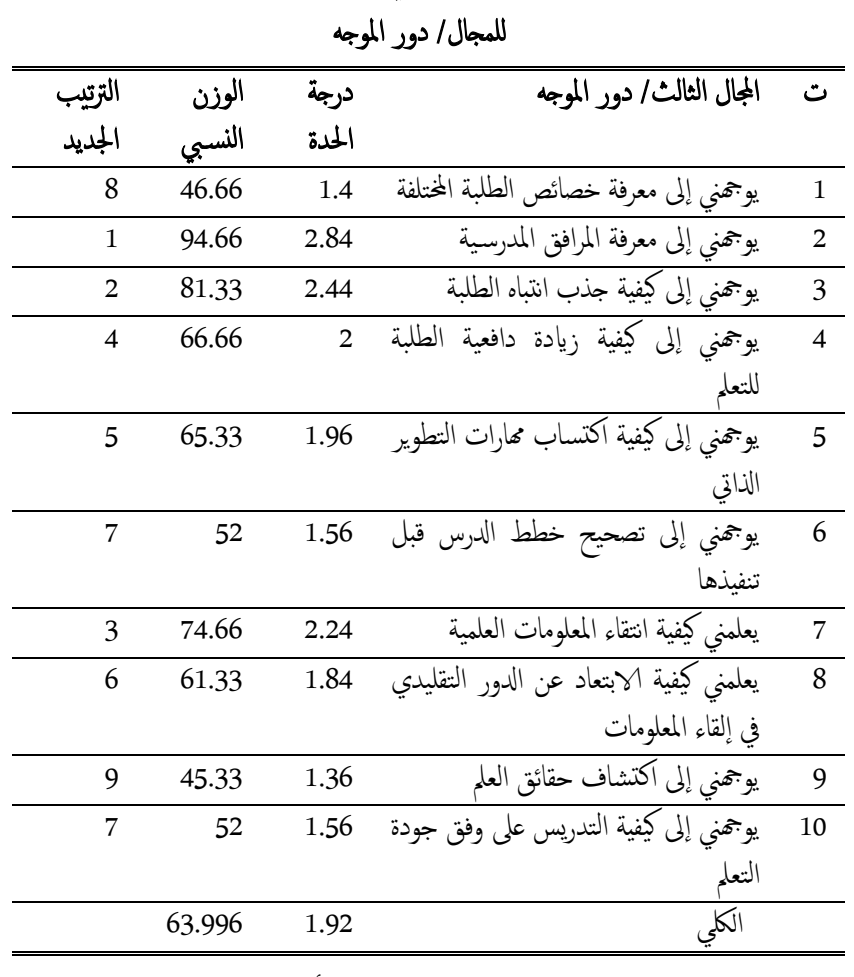

يتضح من الجدول (6) ان بضع القيم بلغت نسبتها أكثر من المتوسط الفرضي البالغ (66) درجة للأداة ككل عدا الفقرات (1,5,6,8,10) على التوالي قد بلغت قيمتها درجة مقبولة ولكن ليس بالمستوى المطلوب وهي أقل من المتوسط الفرضي, وهذا يعني ان تقويم تنفيذ برنامج التربية العملية في مدارس التعلم الأساسي من وبجة نظر الطلبة المطبقين تبعاً لمتغير الجنس ككل قد وبحوا لكن بشكل قليل نوعاً ما الطلبة المطبقين إلى معرفة المرافق المدرسية وكذلك قاموا بتوجيهم ليس بالمستوى المناسب إلى كيفية جذب انتباه الطلبة و علمو هم كيفة انتقاء المعلومات العلمية و يوجتهم إلى كيفية زيادة دافعية الطلبة للتعلم و يوجهم إلى كيفية اكتساب محارات التطوير الذاتي و يعلمهم كيفية الابتعاد عن الدور التقليدي في إلقاء المعلومات ومع قلة توبهمم إلى تصحيح خططهم الندريسية قبل تنفيذها و يوجتهم إلى كفية الندريس على وفق جودة التعلم و يوجحهم إلى معرفة خصائص الطلبة 


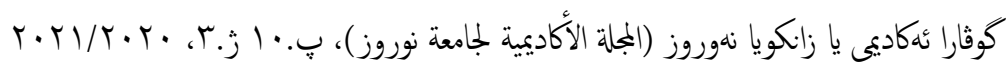

نس المدارس ونفس البيئة المكانية والتي تخضع للتعليات نفها مع اختلاف بسيط بين المدرسين والمدرسات في مدارس التعليم الأساسي.

السؤال الخامس: "هل هناك فرق ذو دلالة احصائية ولمستوى دلالة (0.05) بين درجات وبهتي (ذكور والإناث) في تقوبم تنفيذ برنامج التربية العملية ككل؟؟" وللتحقيق من هذا الهدف استخرجت الباحثة المتوسط الحسابي والانراف

المعياري والقيمة التائية المحسوبة والجدولية كلل كما هو موضح في الجدول (10). جدول رمّ (10) المتوسط المسابي والانحراف المعياري والقيمة التائية المسوبة والجدولية للكل

\begin{tabular}{|c|c|c|c|c|c|c|}
\hline \multirow{2}{*}{ الدلالة } & & القيمة & الانحراف & & العدد & الجنس \\
\hline & القّمة & القيمة & المعياري & الحسابي & & \\
\hline 0.05 & الجدولية & المحسوبة & & & & \\
\hline غير دالة & 2.00 & 0.257 & 9.359 & 70.804 & 33 & ذكور \\
\hline احصائية & & & 12.799 & 71.511 & 33 & اناث \\
\hline
\end{tabular}

يتضح من الجدول (10) ان القيمة الثائية المحسوبة قد بلغت (0.257) وهي أقل من القيمة التائية الجدولية البالغة (2.00) وهذ يعني أنهُ لا يوجد فق ذو دلالة احصائية بين و.جتي نظر طلبة عينة البحث في تقويم تنفيذ برنامج التربية العملية. وتعزي الباحثة هذه النتيجة إلى ان الطلبة (الذكرر, الاناث) أفراد عينة البحث يخضعون إلى نفس برنامج التربية العملية, فضلاً عن ذلك انهم يدرسون في نس المدارس ونس البيئة المكلنية والتي تخضع للتعليات نفها مع اختلاف بسيط بين المدرسين والمدرسات في مدارس التعليم الأساسي.

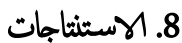

ان المدرسين والمدرسات في مدارس التعليم الأساسي كان لم دوراً إيجابياً في مساعدة الطلبة المطبقين. يوجد تقارب بين وبهتي نظر الطلاب والطالبات في تقويم تنفيذ برنامج التربية العملية لدى الطلبة المطبقين لكل من دور الزميل والمرشد والموجه.

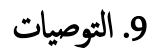
توصي الباحثة الجهات المسئولة بالآتي:

العناية بالجوانب النفسية للطلبة المطبقين، وتوفير الدع والتشجيع لهم. تقديم نماذج تطبيقة للطالب المطبق وبالأخص في الأيام الأولى من بدء

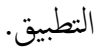

جدول رم (8) المتوسط الحسابي والانحراف المعياري والقمة التائية المسوبة والجدولية للور المرشد

\begin{tabular}{|c|c|c|c|c|c|c|}
\hline \multicolumn{7}{|c|}{ المرثد } \\
\hline مستوى & & القيمة & الانحراف & الوسط & العدد & الجنس \\
\hline الدلالة & القمية & القمية & المعياري & الحسايي & & \\
\hline 0.05 & الجدولية & المحسوبة & & & & \\
\hline غير دالة & 2.00 & 0.754 & 7.363 & 70.560 & 13 & ذكور \\
\hline احصائية & & & 11.592 & 73.431 & 13 & اناث \\
\hline
\end{tabular}

يتضح من الجدول (8) ان القيمة الثائية المحسوبة قد بلغت (0.754) وهي أقل من القيمة التائية الجدولية البالغة (2.00) وهذ يعني أنهُ لا يوجد فق ذو دلالة احصائية بين وبهتي نظر طلبة عينة البحث في تقويم تنفيذ برنامج التربية العملية. وتعزي الباحثة هذه النتيجة إلى ان الطلبة (الذكور, الاناث) أفراد عينة البحث يخضعون إلى نفس برنامج التربية العملية, فضلاً عن ذلك انهم يدرسون في نفس المدارس ونفس البيئة المكانية والتي تخضع للتعليمات نفها مع اختلاف بسيط بين المدرسين والمدرسات في مدارس التعليم الأساسي. السؤال الرابع: "هل هناك فرق ذو دلالة احصائية ولمستوى دلالة (0.05) بين درجات وبهتي (ذكور والإناث) في تقوبم تنفيذ برنامج التربية العملية في دور

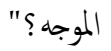
وللتحقيق من هذا الهدف استخرجت الباحثة المتوسط الحسابي والانحراف المعياري والقيمة التائية المحسوبة والجدولية لدور الموجه كما هو موضح في الجدول

جدول رةز (9) المتوسط الحسايي والانحراف المعياري والقيمة الثائية المحسوبة والجدولية لدور الموجه الموجه

\begin{tabular}{|c|c|c|c|c|c|c|}
\hline مستوى الدلالة & \multicolumn{2}{|c|}{ القيمة } & \multirow{3}{*}{ المعياري } & \multirow{3}{*}{ الوسطابي } & \multirow{3}{*}{ العدد } & \multirow{3}{*}{ الجنس } \\
\hline & القيمة & الثيمة & & & & \\
\hline & الجدولية & المحسوبة & & & & \\
\hline \multirow{2}{*}{ احصائية } & \multirow{2}{*}{2.00} & \multirow{2}{*}{0.449} & 11.492 & 66.797 & 10 & ذكور \\
\hline & & & 16.011 & 63.996 & 10 & اناث \\
\hline
\end{tabular}

يتضح من الجدول (9) ان القيمة التائية المحسوبة قد بلغت (0.449) وهي أقل من التيمة التائية الجدولية البالغة (2.00) وهذ يعني أنهُ لا يوجد فق ذو دلالة احصائية بين وبهتي نظر طلبة عينة البحث في تقويم تنفيذ برنامج التربية العملية. وتعزي الباحثة هذه النتيجة إلى ان الطلبة (الذكور, الاناث) أفراد عينة البحث يخضعون إلى نفس برنامج التربية العملية, فضلاً عن ذلك انهم يدرسون في 


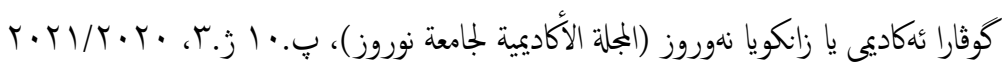

12. خطايبة, ماجد(2002), التزبية العملية والأسس النظرية وتطبيقاتها المدرسية, ط7, دار

$$
\text { التربية الحديثة, دمشق سوريا. }
$$

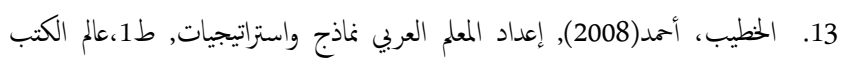

$$
\text { الحيث، عان - الاردن. المعان. }
$$

14. خليفات, نجاح عودة(2013), تربويات المعلم الذي نريد, دار اليازوري العلمية, عان-

15. راشد , علي(1996), اختيار المعلم وإعداده - دليل التربية العملية, دار الفكر العربي,

القاهرة- مصر.

16. زاير وآخرون, سعد علي(2011), المشاهدة الصفية والتطبيق العملي لطلبة الاقسام العربية, ثائر جعفر العصاي للطباعة الفنية الحديثة, بغداد - العرق.

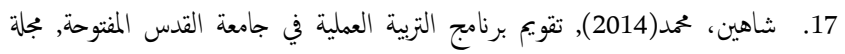

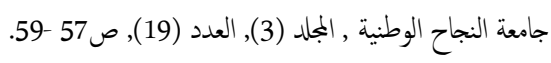

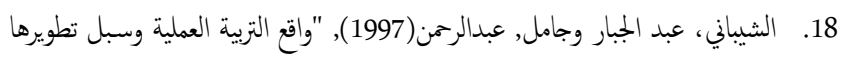

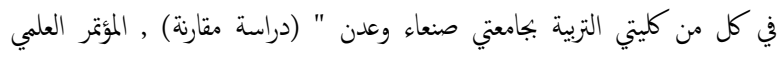

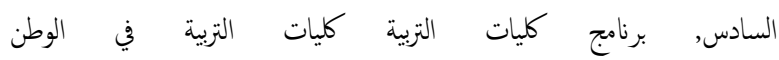
العربي (رؤى مستقبلية), القاهرة,19-31 يوليو. 19. عوض, مهمود محمد حسن(2006), موديول التربية العملية ماهيتها- أهدافها- مراحلها, أسيوط.

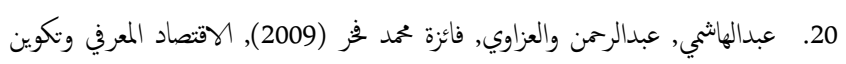
المعلم, دار الكتاب الجامعي, المارارات العربية المتحدة.

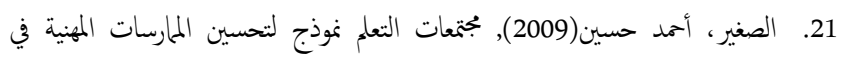

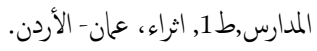
22. الطوالبة، هادي محم(12009), تطبيقات عملية في التربية العملية،1د, دار المسيرة،

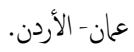
23. عبدلله, عبدالرمن صالح (2004), التربية العملية ومكانتها في برامج التربية العملية, ط1, دار وائل للنشر والتوزيع, عان- الأردن.

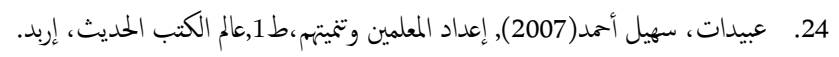

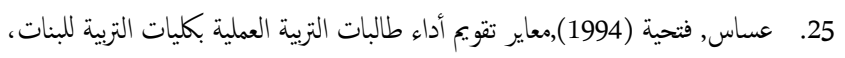
مكتب التربية العربي لدول الخليج، الرياض اض السعودية.

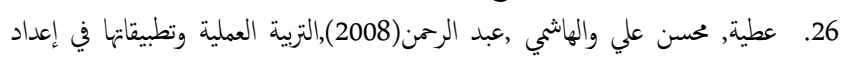
معلم المستقبل, دار المناجه، عان - الاردن. 27. عمر, عبدالرحيم نصرالله(2001), أساسيات في التربية العملية,ط1, دار وائل للنشر

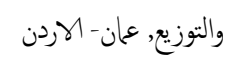

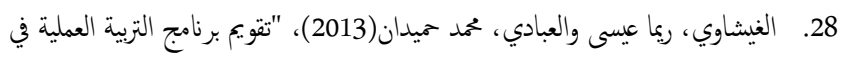

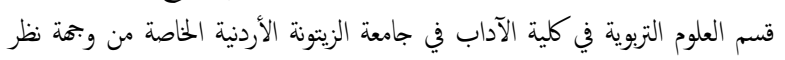

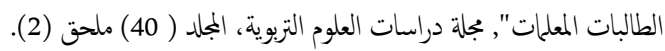

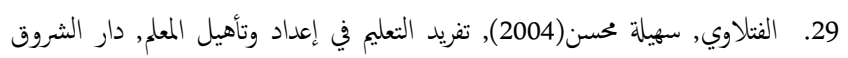

$$
\text { للنشر والتوزيع, عمان- الأردن. }
$$

30. الفتعاوي, الحلام محمد ابراهيم (2011), "تقويم برامج التربية التربية العملية لإعداد المعلم التعليم

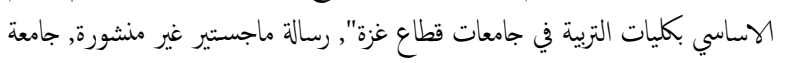
الازهر ,كلية التربية, غزة. 31. كنعان وآخرون(2010)، التربية العملية، جامعة دمشق، مطبعة الروضة، برنامج رياض الم آلمفال.

32. السعيد وآخرون, مزروع (2016),تطبيقات في نظرية ومنهجية الزبية البدنية والرياضية، دار الخلاونية- الجزائر.
توفير المكان المناسب للطلبة/ المطبقين إذ يرى أنه من الأنسب أن ينصهر الطالب/ المطبق مع كادر المدرسة الأساسي, ليتسنى له التكيف مع بيئة المدرسة ويكتسب الحبرة من لدنه. ضرورة توافر التقنيات التعليمية ووسائلها في المدرسة المتعاونة. ضرورة تضمين برنامج إعداد المعلمين في كليات التربية الأساسية المهات الإدارية التي تتطلبها منته.

10. المقتزحات

تقدم الباحثة إجراء البحوث المستقبلية: اكت تقويم برنامج التربية العملية من وجمة نظر مشرف التربية العملية (المشرف التربوي) ومدير المدرسة المتعاونة.

القيام بدراسة لدور المشرف الجامعي والأستاذ المتعاون في برنامج التربية العملية. - n

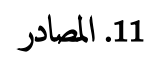

1. 2.

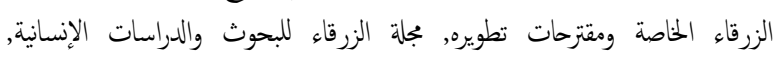

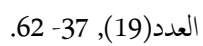

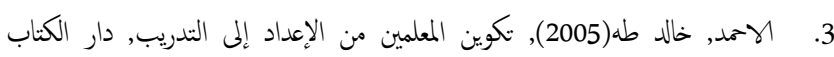
الجامعي, الامارات العربية المتحدة. 4. 5.

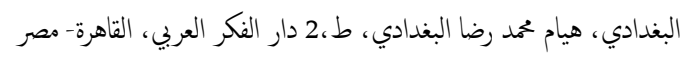

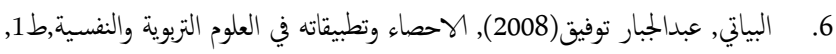
دار اثراء للنشر والثوزيع, عان- الأردن. 7.

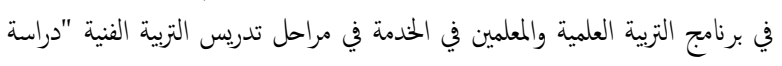

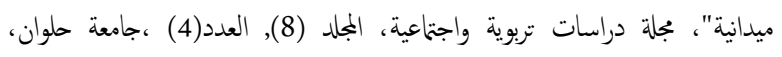
القاهرة- مصر. 8. جرادات وآخرون, عزت(2008),التدريس الفعال, ط1, دار صفاء للنشر والتوزيع, عان- الاردن. 9. حسن حسين زيتون(2004),همارات التدريس رؤية في تنفيذ التدريس، ط2 ،عالم الكنب، القاهرة- مصر.

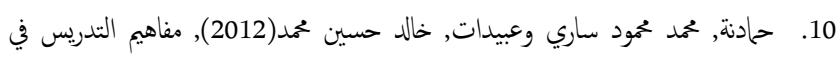

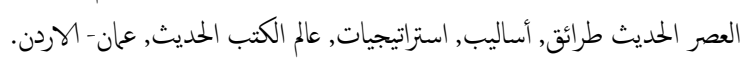

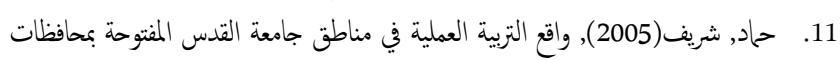

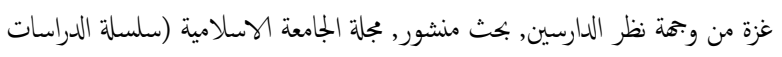
الانسانية), الجملد (13), العدد الأول, جامعة القدس المفتوحة, غزة - فلسطين. 


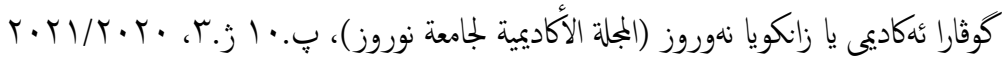
33. الكرداني, فتحي والسائ, مصطنى(2003), التربية العملية بين النظرية والتطبيق، ط1

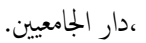

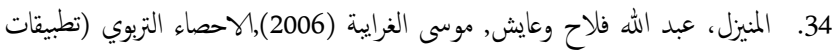

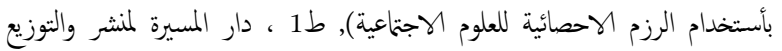

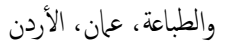
35. محمد, مصطفى وحوالة, سهير (2005), اعداد المعلم تنتيته وتدريبه,ط1, دار الفكر, عان- الاردن. 36. محمود، صلاح (2004), تفريد تعلم عمارات التدريس بين النظرية والتطبيق، ط1, عالم الكتب, القاهرة- مصر. 37. الهاشل, سعد جاسم وممد, محمد عودة (1990), تقويم أثر التزبية العملية في اكساب الكماب

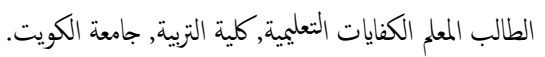

